\title{
A Study of Northeast Natural Consciousness From the Perspective of Manchu Totem Culture
}

\author{
Shu Wang ${ }^{1, *}$ Fanhua $\mathrm{Jia}^{2}$ \\ ${ }^{1}$ Jilin Justice Officer Academy, Changchun, Jilin, China \\ ${ }^{2}$ Changchun University of Science and Technology, Changchun, Jilin, China \\ *Corresponding author. Email: $379906781 @$ qq.com
}

\begin{abstract}
In the primitive times, people believed in certain animals or plants as their ancestors or protectors, believing that they had a supernatural power and would protect the human beings. Therefore, people had the totem worship. The family uses the totem name as the surname, the place of residence is marked by the totem pattern, and the nation uses the totem taboo as the belief. For Manchu, an important representative of the ethnic minorities in the North, the widespread bird and beast totem bears this traditional totem culture. As one of the oldest ethnic minorities in China, the totem culture of Manchu nationality is a relatively unique totem worship style, which is not only the continuation of the ideological worship of ancient people, but also has a profound impact on the modern life of Manchu people.
\end{abstract}

\section{Keywords: Manchu, totem culture, Shaman God, birds and beasts, consciousness study}

\section{INTRODUCTION}

Manchu has a long history. Its origin can be traced back to Sushen nationality in the Shang and Zhou dynasties. Later, Yilei nationality in the Han Dynasty, and the Jin and Jin Dynasties, Wuji nationality in the Northern Wei Dynasty, and Xieji nationality in the Sui and Tang dynasties all have a relationship with Manchu nationality. The direct ancestor of Manchu nationality is the Nvzhen nationality developed from the Heishui Laji. In "The Classic of Mountains and Seas · the classic of Dahuangbei", "there are mountains in the Dahuang, namely, Buxian Mountain. There is a country of Sushen nationality." Buxian Mountains refer to Changbai Mountains today. In "Bamboos of Jin Dynasty · Biography of Four Barbarians", "Sushen (Xishen) lives next to the north of Buxian Mountain", which indicates that the specific living orientation of Sushen nationality is in the north of Changbai Mountains. According to archaeological data, "the Sushen people lived in the areas centered on Mudanjiang and Wusuli River basins." Here the forest is dense, the seasons are distinct, the sea is facing east, and the rivers are like a net. There are many islands and lakes in the estuary of Heilongjiang River. The climate is suitable, and there are a large number of fish and shrimps living in the swamp and lake. It is a good place for human survival, as well as for the survival and reproduction of birds and animals. In such a living environment, the ancestors of Manchu nationality get along with all kinds of birds and beasts day and night. The vigilance characteristics of birds can predict good and bad luck for them, and the beasts can lead the way for the hunters lost in the dense forest. Therefore, Manchu people's worship of bird and beast totem is formed.

\section{THE DIVERSITY CONSCIOUSNESS OF SHAMANISM: "ALL THINGS HAVE SPIRIT"}

The diversity of Manchu totem is directly related to the polytheism that Manchu believe in. Shamanism is a worldwide religious belief, which was first found in Northeast Asia, and is widely popular in northern nationalities in China. The main contents are nature worship, totem worship and ancestor worship. They have a polytheism belief system, i.e. primitive polytheism. They believe that all things are gods, namely, "all things have spirits", which can protect people from disasters. Therefore, the totem symbols used by Manchu nationality are very diverse, involving a large number of animals and plants, such as crows, boars, fish, wolves, deer, eagles, leopards, python, frogs, willows, etc. Among them, snake and python are often regarded as the symbol of evil in Han culture, but they are good gods to protect human beings in Manchu folk belief. Wolf is fierce and wild, similar to Manchu man's ambition, which is the first totem symbol widely used by Manchu people. Niuhulu surname, located in Changbai Mountains, Hunchun and other places, is the oldest surname and one of the largest surnames of the Manchu people. Its main worship object is wolf totem. The meaning of Niuhulu in Manchu language is "wolf on the grassland". 
Manchu nationality is famous for hunting, so eagle has become a totem worship of Manchu nationality. The ancestors knew how to catch eagles very early. After domestication, the captured eagles can help hunters catch other prey. This phenomenon is commonly known as "releasing eagles". According to the Shaman Oracle of the Manchu nationality, "when the sky was just beginning to open, the earth was like a pack of ice. Abu Kahe let a female eagle fly over from the sun, shook her feathers, put light and fire into her feathers, and then sent to the world. From then on, the ice and snow on the earth melt, and people and animals could eat, rest and have children. However, the female eagle was too tired to fly. She dozed off and fell asleep. The fire in her feathers burned the forest and stones red, staying up all night. The eagle quickly used the huge arm to extinguish the fire, and used the huge claw to carry the earth to cover the fire. And then, it died in the sea. The spirit of the eagle turned into the female Shaman. Therefore, the soul of the Shaman is the unyielding eagle.

Manchu people have an indissoluble relationship with eagles. Their reverence for eagles stems from the awesome power. The eagles live in danger, and have extraordinary flying ability and the spirit of the small winning the strong. At the same time, they have developed a pair of extremely vigorous wings in the fierce wind and rain, and also have two sharp eyes through the training of the sun, moon and haze. The eagles can fly for nine days without tiredness, look far and never lose their ways. The colder it is, the more fearless they are going forward." Falco rusticolus, as a brave falcon, not only helps Manchu people hunt, but also melts into Manchu culture. Manchu people show the praise for Falco rusticolus's victory of the small winning the strong, and Falco rusticolus has become the God of Manchu people's faith.

\section{WIDE WORSHIP OF CROWS AND MAGPIES}

Among birds, crows and magpies are widely distributed. Manchu people protect crow tit and treat crow tit kindly. They love crow tit very much. Therefore, there is a widespread worship of crow tit totem in this nation. Exactly, the love and worship of Manchu nationality for birds is one of the characteristics of Manchu culture. In Manchu's bird worship, the worship of crows and magpies is particularly prominent. There are rich images of crows and magpies in Manchu's folk myths and legends.

The reason why Manchu people worship crows is that they believe that crows are the princess to protect the forest, that is, the goddess of the forest sea. With her, hunters can enter the mountains safely. In the past, when hunters offered sacrifices to mountains and forests, they would first provide wine and meat for crows." It is recorded that "the crow used to be the follower of the God of heaven. In the war, it ate black grass by mistake and died. It became the black crow. It flew around the Renmatun stronghold and was used for patrol and hunting." Some Shaman Oracle said: "the feathers of crows are 'like the color when there is no sun', that is, the night. The crow is a black alarm bird. If people have one, people can have a good night. There is a story spreading among the Manchu people. It says that once the forest caught fire, the Manchu God of hunting sent crows to wake people up to put out the fire. After the fire was extinguished, half of the trees had been burned. For this reason, the God of hunting decided to punish those who did not extinguish the fire, and sent crows to mark the people who fought against the fire, with beads in their mouths. Those who did not have signs would be punished.

The records about magpies are spread around Ningguta. It is recorded in the myth that, the God Shakesha to forecast some good and bad luck when seeing that human beings do not know how to prevent natural disasters, sent. He was born in an old hunter's house by thankful pregnant. He was characterized by a half man and half magpie. He grew up in a magpie nest and accompanied magpies all day long. He forecast floods and pestilence, which saved the tribe from disaster. He saw through the enchanted array, rescued the people, and was regarded as the God of joy by the Manchu nationality. Since then, whenever welcoming new people, building new houses, recovering from a long illness, sending troops to fight and coming back safely, the Manchu people will sacrifice joy to God.

In the traditional story, it is recorded that Doron Princess is looking for someone who can subdue the demon Peng. At this time, a white magpie spits out human language and points out the direction for Doron Princess. Wanda and Nvzhen have tried their best to retrieve the water drops stolen by the evil dragon to eliminate the flood. Wanda died in the battle and became a mountain. His two eyes turned into two magpies, leading Nuzhen and her daughter to find Wanda's treasure axe. In "The Delightful Forest", Zhushen's good friend, a little magpie, leads Zhushen's husband to find Zhushen, who runs away from home, so that the two never separate. In "Baiyun Princess", magpies called on Baiyun Princess, the third daughter of the God, and she dropped green branches to save the human beings and living things in the flood.

In myth, crows and magpies have human nature or divinity, and can help human beings or gods achieve the goal of saving human beings. In the Manchu myth of Jinyuan area, magpies and crows are the children of fairies. After being drowned by the flood, they are transformed into crows and magpies. They bring grain seeds and Ceres to the Nvzhen nationality. The agricultural production of the Nvzhen nationality is increasingly developed and the Wanyan nationality is 
increasingly powerful. They believe that magpies and crows are the emissary sent down by heaven. The crow and magpie can protect people from disasters.

\section{STRONG ANCESTRAL CONSCIOUSNESS AND IMMORTAL CONSCIOUSNESS}

In the story of Manchu nationality, there are many legends about the crows and magpies saving human beings, which is another reason why Manchu people worship crow and magpie totem. The most familiar story is the legend that crows rescued Nurhachi. "Nurhachi was chased by the soldiers of Ming Dynasty. He was about to be caught up. A group of crows covered him. When the soldiers of Ming Dynasty saw a group of crows afar, he decided that there was no one in this place. So the crows saved his life. The Manchu people attached the legendary hero to Nurhachi, the founding monarch, which not only showed the noble birth and miraculous deeds of the leading figures, but also increased the influence of the legend, making the story of crows and magpies widely spread in the northeast. The later generations of Manchu nationality all took magpies as gods. And they not only kept magpies from being hurt, but also kept them in the northeast corner of Shengjing.

On the basis of totem worship, animal worship has gradually evolved. Animals play a very important role in the social life of the Manchu people. It embodies the concept of animal worship of the Manchu ancestors, and also reflects the important role of animals in the hunting life of the Manchu ancestors. In particular, some animals with certain mysterious colors are endowed with some magical abilities artificially, and then there is a sense of immortality as a God. Baojiaxian, which is widely worshipped in Northeast China, is the direct embodiment of this kind of animal worship.

Baojiaxian mainly refers to fox, weasel, snake and python. It is believed that Baojiaxian has the function of protecting family peace and harmony. Influenced by the worship of foxes and gods of the Han nationality, the Manchu people have an unusual belief in foxes, and have two extreme attitudes towards foxes. On the one hand, they worship fox immortals and offer sacrifices to them; on the other hand, they think that foxes harm people, confuse people and weaken people's spirits. Such foxes make them worship foxes. At the same time, they have the contradictory psychology of fear for foxes. They generally think that foxes are very vindictive and people can't provoke them easily. Foxes are too cunning and can't be hit easily. Once hit, people will be retaliated by foxes. Therefore, people generally don't hit foxes. Manchu people generally believe that Fox fairy is kind, and it can bring good luck to people.
In Northeast China, weasels are generally considered to be impatient and naughty, so they are also called "yellow naughty". It is dexterous in body, cunning in temperament, and can easily enter and leave very narrow gaps, making people feel mysterious. This special function has been considered as the power of the "immortal family" by many people. Therefore, people are full of awe, and the weasel is regarded as the yellow fairy full of mystery to worship. In the daytime, people often see weasels bowing to the sun or asking for a seal. It is said that "asking for a seal" is the key to whether weasels become immortals. Therefore, if people say the sentence "you can become immortals" and worship them, they will shake their heads and swing their tails and leave happily. On the contrary, the northeast folk custom thinks that if the weasel is violated, it will harm people at any time, people will have headaches and other symptoms, and even mental disorders and crazy jumping in the house. It is said that as long as a doctor, a wizard or a person who has beaten a weasel coughs outside the door, the attack will stop immediately, and the person acts like a normal person. Therefore, there will be temples and ancestral halls of different sizes in the northeast to worship Huangdaxian on a fixed date to protect the safety of the house.

In addition, tigers, bears, pigs, Phoenix, etc. are also endowed with spiritual consciousness. Tiger worship is an important worship belief that has existed in the northern ethnic group since ancient times. Influenced by the primitive Shamanism animal worship, tiger is regarded as a mountain god among the Manchu people, which is not found in other ethnic stories and has unique characteristics of mountain forest hunting culture. The mountain god is an old man with white hair and white beard imagined by the hunters in the mountain forest. $\mathrm{He}$ is in charge of all kinds of animal and plant resources in the mountain forest. If the hunters want to catch the prey, they must worship the mountain god before and after going to the mountain to get his blessing. The hunters are very careful and respectful to the tiger. The hunter never beats the tiger. After the tiger is injured, he will risk his life and try his best to cure it. In the concept of Manchu people, tiger is regarded as a powerful symbol, also a symbol of ferocity, and the king of all animals in the forest. People here admire its power, treachery and cleverness. The tiger gallops through the mountains and forests with its ferocious animal nature and vigorous posture. People worship it and pray for courage and disaster elimination. It is not only a kind of natural worship, but also the belief that people are related to the tiger by blood, and the tiger is the ancestor and its offspring.

During the Liao and Jin Dynasties, the northern minorities began to accept the Phoenix culture and gradually respected it. The phoenix worship is consistent with the Manchu Shaman folk belief. In Shaman's concept, the worship of birds occupies a very 
important position. Birds are regarded as the symbol of soul. Birds, such as eagles, swans, crows and magpies, have the divinity. Undoubtedly, these birds have become the prey objects of Phoenix. It is the birds worshipped by Shaman believers, having the basis of the same worship of phoenix.

On the other hand, phoenix worship also conforms to Shaman's concept of sun worship, which belongs to the category of natural worship and is one of the most basic worship of primitive people. In the ancient people's mind, the sun is obviously a God that can bring light and warmth to the world. People's surprise and fear of strong natural power form the basis of deification and worship of the sun. The life of nomadic, fishing and hunting people in the north mostly depends on the changes of the sun, the moon and the stars, so the sun is regarded as the hunting God by them. Because of the image of Phoenix bird, people think that it likes light and warmth, chirps and flutters its wings as the sun rises in the East, nests and perches trees as the sun sets in the west, and worships it as the embodiment of the sun. It can be seen that phoenix worship originates from animal worship, but it is beyond animal worship and becomes a kind of "God" worship. In Manchu belief, Phoenix becomes auspicious bird. Its appearance will bring good luck and well-being. People use it to express their good wishes, such as harmony, stability, prosperity and so on. It also implies the worship of love and light.

In a word, the natural gods, totem gods and ancestor gods respected by the Manchu generations play an important role in their survival and life process, bear special mission, and form a solidified cultural memory in the blood of generations.

\section{THE MODERN CONTINUATION OF MANCHU TOTEM CULTURE}

\section{A. Application of totem culture to the field of modern clothing}

The costumes of all dynasties in China have their own characteristics, and totem culture has a long history of application in costumes. At first, the use of totem patterns in the traditional costumes of the Chinese dynasty was a political means. With the progress of the society, totem began to express people's wishes for peace, auspiciousness and aesthetic concept in clothing. In the Qing Dynasty, the Manchu royal family and the folk worshipped the phoenix culture to the extreme. Different from the imperial court worshipping power, the folk paid more attention to the decoration of the phoenix image and regarded it as a beautiful plastic art. People also embroidered the pattern of "dragon and Phoenix bringing happiness" on the standing cap, knee and other places that people wear every day.

\section{B. Application of totem in logo design}

China's logo design has developed from the original tribal totem to the modern logo. After a long development process, adding totem elements to the modern logo design not only increases the cultural connotation, enhances the design appeal, but also highlights the nationality of logo design. The totem culture of Manchu nationality is cleverly used in modern logo design.

The application of Manchu totem culture in ancient Chinese signs is relatively simple, mainly including various types of "Fu" and "Pai", such as the "Fu" and "Pai" used when entering the palace or passing through the gate. The material of "Fu" and "Pai" is mostly made of wood or metal. Since the Spring and Autumn period, in order to ensure the needs of military operations and the requirements of confidentiality and anticounterfeiting, the "Fu" and "Pai" began to step on the historical stage gradually, leaving a strong ink. The mature totem symbol elements have been used in bronze ware. By conveying the meaning, they have the characteristics of symbolization.

Chinese ancient totem symbol is the source of Chinese modern logo design. In recent years, the totem symbols of Manchu nationality are more and more widely used by people. The totem of ancient China has important aesthetic value and gives many references to modern logo design. Because of the characteristics of Totem's own national culture and nativity, totem has become the most element symbol with Chinese characteristics in the local culture, which is not only a new manufacture of distinguishable national culture, but also the inheritance of the original totem culture.

\section{Totem creativity of advertising media}

In the advertising practice, it is a unique artistic expression method to combine with the traditional Chinese totem cultural elements for advertising creativity. China is the country with the longest and most splendid culture in the world, with many nationalities and diverse totem culture worship. Many foreign brands start to use the traditional Chinese cultural elements widely when they enter the Chinese market, including Manchu crow and magpie totem culture. The crows, magpies, wolves, deer, eagles, leopards and other elements in the totem worship of the Manchu people form a splendid cultural river.

\section{ConClusion}

Totem originates from the reverence of human ancestors for nature, and is also the earliest symbol of social groups. As an important part of Chinese traditional culture, Manchu totem culture has its own unique color art, line art, painting skills and regional cultural connotation. With the excavation of intangible 
cultural heritage, the cultural value is gradually found and valued. As an art form closely related to life in ancient times, it is not only loved by the Manchu people, but also more and more concerned by the society. Through the interpretation of the rich cultural connotation of the Manchu totem, the value of the totem culture can be better inherited.

\section{References}

[1] Transitional Measures on the Implementation of the Amended Patent Law [J]. China's Foreign Trade. 2010(03).

[2] Li Di. The Beauty and Sorrow of Primitive Grassland-The Totem Shock and Impact of Wolf Totem [J]. Journal of Heilongjiang College of Education, 2006-02.

[3] Li Yiyin, Cui Haiting, Hu Jinming. Analysis on the Ecological Background of Ancient Civilization in the West Liao River Basin [J]. Quaternary Research, 2003 (03)

[4] Selected Manchu Folk Tales [M]. Chunfeng Literature and Art Publishing House, 1983.

[5] Fu Yuguang.Fu Yuguang's Folklore Culture Collection [M]. Jilin University Press, 2005.

[6] China's First Historical Archives. Old Manchu Archives [M]. Zhonghua Book Company, 1990.

[7] Wang Wei. Exploring the Origin of Shang Culture's Jade Articles [J]. Archaeology, 1989 (09).

[8] He Xingliang. Totem and the Origin of God [J]. EthnoResearch, 1989 (04).

[9] Zhu Naicheng. The Age of Yanhuang and the Origin and Formation of Chinese Civilization [J]. Journal of Xinyang Teachers College (Philosophy and Social Science Edition), 2019 (03).

[10] Yan Yugang. Several Opinions on Curriculum Setting and Talent Cultivation for Culture Industry $[\mathrm{J}]$. Qilu Normal University Journal, 2009 (5):47.

[11] Zong Jing. Research on the characteristics of totems in national costumes [D]. Tianjin University of Technology, 2006.

[12] Zhang Cong. Analysis of China's Diverse National Costumes [J]. Western Leather, 2018 (07).

[13] Wang Yingjie. Totem Culture's Expression in Costume Design [J]. Jiannan Literature (Classic Christian Garden), 2013 (10).

[14] Wu Xibiao, Chen Yingjing. Remains of Totem Worship in Minority Costumes [J]. Journal of Guangxi University for Nationalities (Philosophy and Social Science Edition), 2003 (06) 